\title{
MOTHER MAY I? \\ IMPOSING MANDATORY PROSPECTIVE RULES OF STATUTORY INTERPRETATION
}

\author{
Larry Alexander* and Saikrishna Prakash**
}

Suppose an imperious woman announces that, henceforth, she will construe the sentences of others as completely meaningless unless each sentence is preceded by the obsequious question "Mother May I?" When this domineering woman proceeds to ignore sentences that do not begin with "Mother May I" because she deems them to be gibberish, is she really engaged in any recognizable form of "interpretation"? We think not. Her artificial rule, completely unrelated to conventional understandings of words or the intentions of the speakers, has made it highly unlikely that she is engaging in anything remotely resembling interpretation. To treat the expressions of others as gibberish just because they omit "Mother May I" is to misunderstand, not "interpret," what their words mean.

Suppose the imperious woman is also more than slightly addled and announces to the world that henceforth, her own vocalizations are to be treated as nothing but gibberish by others unless she first precedes each of her sentences with "I am talking to you." If in the future she falls to the ground, writhing in pain, and calls out for help, begging someone to call a doctor, should the world ignore her apparent entreaty because she did not utter the magic words in her time of need? Once again, we think not. If we want to respect her wishes at the time she collapses, we ought to come to her aid. Though her second artificial rule of construction requests that we depart from the meaning of her subsequent expressions when they are not preceded by the required words, if we are to follow the meaning of those subsequent expressions, we ought to recognize that she really is calling

* Warren Distinguished Professor of Law, University of San Diego.

** Professor of Law, University of San Diego. We wish to thank Elaine Alexander, Laurie Claus, Mike Rappaport, Steve Smith, and Larry Solum for their comments. 
for help. If we ignore her appeals, we are ignoring what she wants now.

Nicholas Rosenkranz, in his recent excellent article in the Harvard Law Review, ${ }^{1}$ essentially suggests that in the first scenario, when the woman ignores the communications of others that are not prefaced with the all-important question, the woman is nonetheless engaged in interpretation. Likewise, we think Rosenkranz is committed to the view that the woman's apparent plea for help in the second scenario is not a call for help at all but is instead gibberish because it too was not preceded by words that would make it clear that the woman was engaged in purposeful communication with others. To be sure, Rosenkranz's article is not about bossy men or women at all. Instead, his article is about the constitutionality of mandatory prospective rules of statutory interpretation created by Congress and the federal judiciary. But if one substitutes the judiciary for the woman in first example and the Congress for the woman in the second scenario, we think that Rosenkranz would require "interpreters" to ignore the communications discussed in both scenarios. In both situations, the relevant "lawmaker" has decreed that magic words must be uttered if there is to be meaningful communication. In the absence of these magic words, the relevant expressions/statutes have no meaning, or at least that is what Rosenkranz would have us believe.

We think that Rosenkranz is mistaken. In our view, statutes (and words more generally) have meanings independent of (and sometimes contrary to) any mandatory rules of interpretation that Congress or the judiciary might have laid down in the past. ${ }^{2}$ Artificial rules of interpretation laid down in advance that do not reflect subsequent usages or intentions should not be allowed to trump the actual meaning of statutes. For instance, if a future Congress uses the phrase "marriage" in a statute to clearly encompass unions between two gay men or two lesbian women, ${ }^{3}$

1. Nicholas Quinn Rosenkranz, Federal Rules of Statutory Interpretation, 115 HARV. L. REV. 2085 (2002).

2. None of the claims we make here apply to Rosenkranz's interesting (and we think correct) view that Congress could pass mandatory rules of interpretation for prior statutes. Moreover, we also believe that Rosenkranz is correct that Congress could enact mandatory rules of interpretation that are to apply to the very act which created the mandatory rules of interpretation. In both these cases, Congress is not purporting to constrain future Congresses but is instead arguably modifying how prior laws or the statute at hand is to be interpreted.

3. An intentionalist might think it crystal clear that Congress meant marriage to encompass such relationships if every member of Congress were part of such gay marriages. A textualist might think it crystal clear that the most recent statute covers gay and 
"marriage" in that statute should be so understood despite the seemingly ironclad definition of marriage found in the Dictionary Act. ${ }^{4}$ In our view, one is not engaging in interpretation of the second act if one allows the Dictionary Act's definition of marriage to trump the meaning of marriage in the second statute. Likewise, if a future Congress passes a one-sentence statute (statute A) that only acts to repeal an existing one-sentence statute (statute B) that in turn had repealed another (statute C), the likely meaning and effect of statute $A$ is to revive statute $C$. There is no other way of making sense of the repeal of the repealing statute. This is true despite the fact that there is a rule of construction in Title 1 that requires the express revival of statute $A$ in statute $C$ if statute $A$ is to be revived.'

We should not be understood as insisting that Congress may not pass prospective interpretive guidelines that suggest what future Congresses might mean when they use a particular word or phrase in subsequently enacted statutes. Such statutory guidelines, though they cannot directly affect a subsequent statute's actual meaning, can make it more likely that the actual meaning will be consistent with the meaning suggested by the prospective interpretive guidelines. When subsequently drafting a statute, Congress might take into account the guidelines announced in the first statute, just as a Congress might very well take into account dictionary definitions when drafting statutes. ${ }^{6}$

However, we are claiming that Congress cannot pass mandatory prospective rules of interpretation that purport to oblige interpreters of future statutes (be those interpreters members of the executive or judicial branches or the general public). Because the lodestar of statutory interpretation is the discernment of the statute's meaning, binding rules of interpretation of whatever sort must be ignored when an interpreter decides that the

lesbian marriages if at the time the second statute is enacted the most common meaning of marriage covers both heterosexual and homosexual marriages.

4. 1 U.S.C. $\$ 7$ (2002) ("the word 'marriage' means only a legal union between one man and one woman as husband and wife").

5. 1 U.S.C. $\$ 108(2002)$ ("Whenever an Act is repealed, which repealed a former Act, such former Act shall not thereby be revived, unless it shall be expressly so provided").

6. Thus we have no quarrel with prospective interpretive guidelines that make clear that they are not mandatory, binding rules. For instance a prospective definition that words "importing the plural include the singular" that is modified by the limitation "unless the context indicates otherwise" seems to us entirely unobjectionable. See 1 U.S.C. $\$ 1$ (2002). This prospective interpretive guideline makes it clear that prospective uses of plural nouns need not necessarily be read as encompassing singular nouns as well. 
meaning of a statute differs from the constructed "meaning" derived from the application of binding rules of construction.

Thus, a statute that mandated that the word "person" be construed in subsequently enacted statutes as including corporations and partnerships could not constitutionally require that interpreters of a subsequent statute actually understand "person" to include corporations and partnerships when it is clear that the subsequent statute uses "person" in the more familiar, natural person sense of the word. For instance, if a subsequently enacted bankruptcy statute has two sections, one that addresses bankruptcies of "persons," and one that speaks of bankruptcies of "corporation and partnerships," one probably should not construe the statute as allowing corporations and partnerships effectively to choose between the two different bankruptcy sections. Instead, it seems likely that the meaning of the statute (under either a textualist or intentionalist approach) is that corporations and partnerships may only file under the section specifically designed for corporations and partnerships, notwithstanding the preexisting statutory definition that made corporations and partnerships "persons."

Contrary to Mr. Rosenkranz's claim that the meaning of a statute is merely "derived ... by bringing interpretive rules to bear upon it," we think that a statute's meaning (and the meaning of words and sentences more generally) is independent of whatever artificial rules that legislators and judges might create to either constrain themselves or others. ${ }^{8}$ In particular, we are intentionalists and believe that the meanings of words are those meanings intended by the author(s) or speaker(s). As should be obvious, if the goal is to understand the intentions of authors and speakers, one cannot be artificially constrained by fixed meanings or rules. If one allows these meanings or rules to trump the

7. We are not claiming that one cannot imagine a statute that actually gives corporations and partnerships the choice of proceeding along two different statutory routes. We are saying that given the way the statute is drafted, it seems likely that reading this hypothetical statute as if it gives partnerships and corporations two options instead of one is to misapprehend the meaning of the statute.

8. Others have made claims similar to Mr. Rosenkranz but then have gone on to discuss differences between a statute's actual meaning and the artificial meaning derived from the application of the rules of interpretation. See Cass R. Sunstein, Interpreting Statutes in the Regulatory State, 103 HARV. L. REV. 405, 423, 434, 450, 456 (1989). If meaning were solely a function of enacted rules of interpretation, however, such a gap between actual meaning and the meaning derived from application of interpretive rules could not exist. See Larry Alexander, All or Nothing at All: The Intentions of Authorities and the Authority of Intentions, in LAW AND INTERPRETATION 357, 394-95 (A. Marmor ed., 1995). 
intended meaning when the intent of the authors or speakers is clear, one no longer has an intentionalist approach. ${ }^{9}$

Textualists ought to have problems with mandatory interpretive rules as well. A follower of Justice Scalia, who believes that the meaning of words found in statutes is to be found in the most common public meaning of those words, must object when Congress enacts a definition for a word or adopts a canon of interpretation that is wholly contrary to common usage. For instance if Congress, in a fit of perversity, adopts a prospective statutory rule that "'State' shall be construed to include U.S. territories and the District of Columbia," that rule must be ignored when Congress subsequently enacts a statute that creates interstate commercial rules only for the " 50 States." If a textualist is to stay true to the view that the meanings of words are established by their most common public meaning, the textualist must ignore the statutory command to understand States to include territories and the District of Columbia in subsequent statutes.

9. Because we are intentionalists, we reject textualism. Though we do not wish to engage in a full-blown debate about the relative merits of the two theories, we make a few brief points here. We note that even the most ardent textualists make assumptions about context. For example, they assume that "keep off the grass" has a different meaning if it is on a yard sign rather than a sign over a drug counselor's office. See LARRY Alexander \& Emily SHerwin, The Rule of Rules: Morality, Rules, And the DILEMMAS OF LAW 243 n.8 (2001); KENT GREENAWALT, STATUTORY INTERPRETATION: 20 QUESTIONS $38-39$ (1999). Likewise textualists often ignore punctuation rules that derogate from the meaning they know was intended. See, for example, the first sentence of the Seventeenth Amendment, where the comma would in standard grammar indicate a six-year life for the amendment rather than six-year terms for Senators, or clause 1, section 3 of Article IV, which would, given its semicolons, cast doubt on whether Congress could, through its consent, make West Virginia a constitutionally legitimate state. See Peter Jeremy Smith, Commas, Constitutional Grammar, and the Straight-Face Test: What If Conan the Grammarian Were a Strict Textualist?, 16 CONST. COMMENT. 7 (1999); Michael Stokes Paulsen \& Vasan Kesavan, Is West Virginia Unconstitutional?, 90 CAL. L. REV. 291 (2002). More basically, textualists assume that the Constitution and statutes are written in English. But no text by itself declares the language in which it is written. See Laurence H. Tribe, Comment, in ANTONIN SCALIA, A MATTER OF INTERPRETATION 65, $76-77$ (A. Gutmann, ed., 1997); ALEXANDER \& SHERWIN, supra, at 242 n.1. Rather, the context-English-speaking authors writing to direct an English-speaking audience - shows that English was the language intended. (Rosenkranz recognizes this point but fails to see its tellingness vis-à-vis statutes' having independent meanings versus meanings dictated solely by interpretive rules. See Rosenkranz, supra note 1, at $2113 \mathrm{n} .111$. That a statute is in English cannot logically be the product of another statute to that effect.) For all these reasons (and others), we are of the view that even the most ardent textualists are closet intentionalists because they make certain assumptions about the text that are not based solely on the text.

Despite these arguments for choosing intentionalism over textualism as the lodestar of interpretation, our case against binding rules of interpretation does not rest on them. Whether one is an intentionalist or a textualist, so long as one believes statutes have meanings independent of what binding rules would dictate, one must reject such rules. 
If we are right that words and sentences often have meanings independent of those "meanings" generated by the mechanical application of various interpretive rules cited by courts and scholars, why is someone as smart as Mr. Rosenkranz led to the belief that Congress may prospectively require that future interpreters apply mandatory definitions and rules of construction? We think that Rosenkranz is moved by the fact that the courts have created various mandatory rules of interpretation that effectively require Congress to explicitly circumvent them in order to avoid their sting. Courts arguably have created rules of statutory interpretation with respect to federalism ${ }^{10}$ and avoidance of constitutional interpretation in statutory cases. ${ }^{11}$ If the courts can do this, Mr. Rosenkranz argues, why not Congress?

We disagree with the foundation of Rosenkranz's argument. In our view, the federal judiciary has no authority to create binding rules of interpretation that it will use to construe federal statutes. To the extent the rules of interpretation help attain results that merely mirror the meaning that one would otherwise derive from a statute, the rules are harmless because they merely articulate the proper way of divining meaning at the time they are applied. ${ }^{12}$ But to the extent that the rules of interpretation create an artificial meaning that is divorced from the meaning that one would discover in the absence of the rules of interpretation, we think that such rules of interpretation are constitutionally problematic. In what way does the "judicial power of the United States" grant the federal judiciary the authority to create counterintuitive rules of interpretation that then require the Congress affirmatively to circumvent them? We doubt that the judicial power-the power to decide cases-gives the federal judiciary the power to dictate interpretive rules to Congress. The courts cannot dictate (or constrain) how Congress must express itself.

10. See Will v. Michigan Dep't of State Police, 491 U.S. 58, 65 (1989) (quoting Atascadero State Hosp. v. Scanlon, 473 U.S. 234, 242 (1985) ("the ordinary rule of statutory construction [is] that if Congress intends to alter the 'usual constitutional balance between the States and the Federal Government,' it must make its intention to do so 'unmistakably clear in the language of the statute"')).

11. Ashwander v. Tennessee Valley Auth., 297 U.S. 288, 341 (Brandeis, J., concurring) (citation omitted); Edward J. DeBartolo Corp. v. Florida Gulf \& Coast Bldg. \& Constr. Trades Council, 485 U.S. 575 (1988) (citation omitted).

12. In other words, if judicial canons of statutory interpretation are merely evidentiary rules of thumb that correspond to natural probabilities of intended meaning, they are unproblematic. 
To be sure, Congress can always circumvent whatever rules of interpretation that the judiciary might announce. But that ability does not answer the question of whether the judiciary has the constitutional authority to throw up such roadblocks to meaning in the first place. If Rosenkranz and the conventional wisdom are right, the federal judiciary should be able to tell Congress that unless future federal statutes include a paean to judicial supremacy, the judiciary will interpret them as if they were non-binding resolutions. Likewise, if conventional wisdom is right, the judiciary may declare that it will construe subsequently enacted statutes as if they were in German unless the statutes begin with an express statement, in German, that the statute is to be construed in another language. ${ }^{13}$ The extreme nature of these hypotheticals is necessary to make the point; we do not believe that the judiciary may erect artificial barriers to meaning and force Congress explicitly to circumvent them. Because actual meaning is what counts (independent of whatever "meaning" judicially-created rules of construction might suggest), the courts must construe statutes consistently with their actual meaning and not pay heed to whatever counterintuitive rules the judiciary might announce. ${ }^{14}$

An analogy may highlight the problems with the judiciary's creating rules of interpretation that cannot be overcome by Congress except by express repeal or express circumvention. Under the Constitution, the President may veto legislation (preventing it from having the effect of law) if he returns the legislation to the originating chamber along with his "objections." 15 Could Congress properly pass a statute that requires the President to use a certain set of words - say, "I object"-if he wishes to veto legislation? More precisely, if the President returns a bill with his objections, and it is otherwise obvious that he sought to veto the bill (either from his accompanying letter or from evidence of his intentions more generally), may Congress nonetheless treat the legislation as if it became law because the President never used the crucial phrase "I object" when he returned the

13. Interestingly enough, in 1795 Congress actually considered publishing federal laws in English and German. But that proposal went nowhere. For an extended discussion of the urban legend surrounding this episode, see http://www.watzmann.net/scg/ german-by-one-vote.html.

14. We are hardly the first to question the judiciary's power to create rules of interpretation that are counterintuitive. Justice Scalia "doubt[s]" whether the judiciary can "just decree that [it] will interpret the laws that Congress passes to mean less or more than what they fairly say." SCALIA, supra note 9, at 29.

15. U.S. CONST. art. I, $\$ 7$, cl. $2,3$. 
legislation? We think the Constitution grants the President the right to express his objections however he likes, and Congress cannot circumscribe how the President might express them. If it is discernible that the President has returned a bill with "objections," the Congress cannot treat the vetoed legislation as if it were law. Should Congress wish the bill to become law nonetheless, it must override the President's veto.

Likewise, in our view Congress is free to express its laws in whatever form or language it wishes. ${ }^{16}$ The Constitution grants the legislature the right to pass legislation, and the judiciary cannot erect obstacles to the manner in which Congress might choose to express its will. Accordingly, if the meaning of a statute is discernible, it is this actual meaning that must matter to judges and not some hypothetical meaning created from the application of judicially established rules of construction. Though judges wield tremendous power, we do not believe that they have the constitutional authority to modify the meanings of words and sentences. ${ }^{17}$

We could express our objection in another way. In a sense, we do not believe that the judiciary may constitutionally enforce a judicially crafted rule against implied repeals or exceptions to judicially-crafted rules of interpretations. Because the meaning of the statute is what matters, so long as the meaning of a statute indicates an implied repeal of a judicially created rule of interpretation, the judiciary should treat the statute as having repealed (or as having created an exception to) that rule of interpretation. ${ }^{18}$ If a judicially crafted rule of interpretation cannot constitutionally prevent either express or implied repeals, it has

16. Assuredly, if Congress chooses to express itself in an obscure or unknown language, the executive and the judiciary (along with the public) will run into practical difficulties in discerning the intent of Congress. But such difficulties do not mean that Congress lacks the power to decide how it wishes to express itself. They just suggest that Congress ought to be pragmatic in expressing itself lest its intentions become too difficult to discern.

17. For this reason, we believe judicially-created rules like that of Ashwander v. TVA, 297 U.S. 288 (1936), which deems ambiguous statutes to "mean" whatever would avoid a constitutional issue, to be themselves constitutionally invalid. See Frederick Schauer, Ashwander Revisited, 1995 SUP. CT. REV. 71.

18. For instance, we share Justice Scalia's view that "[t]he rule that statutes in derogation of the common law will be narrowly construed seems like a sheer judicial powergrab." See SCAliA, supra note 9, at 29 . It is a power-grab, both because it was retrospective, and because the rule, applied prospectively, is likely to lead to results that are contrary to the statute's meaning. More to the point, the judicially created rule requires express preemption of the common law and therefore creates the potential for the constructed meaning that emerges from the application of the judicially created rules to diverge from the actual meaning. 
no range of constitutional applications as a mandatory rule. It is thus really no rule at all, but at most an evidentiary guideline.

If the judiciary has no constitutional authority to create mandatory, prospective rules of statutory interpretation, what about Congress? Though Rosenkranz built his argument that Congress could pass canons of construction on the shaky edifice of the judiciary's problematic adoption of rules of construction, it does not follow that he is wrong about what authority Congress might have vis-à-vis its own statutes. Even though Congress would be passing prospective rules of interpretation that would apply to its own statutes, we do not believe that Congress has such power. Congress cannot so constrain itself.

We start with the unremarkable proposition that Congress may not add to the constitutional requirements necessary to pass a law. Under the Constitution, any Congress may make statutes out of bills if the bills undergo bicameralism and presentment. No Congress may require by statute that future members of Congress clap their hands prior to legislating, or think deep constitutional thoughts prior to passing a bill related to the Constitution, or spin around three times prior to repealing a statute. Congress lacks the direct legislative authority that would authorize such statutes, and it is difficult to see how such a statute would be "necessary and proper" to carry into execution any power of either Congress or of the federal government more generally. We believe that Rosenkranz agrees with our claim thus far. We do not believe that he possibly holds the view that any Congress may require future Congresses to bark like seals prior to legislating.

What is true of these physical actions is true of required texts as well. Congress may not force a future Congress to use particular language to legislate. If a meaning emerges from a statute, that meaning must control, rather than some artificial meaning that emerges from an inflexible adherence to rule of interpretation promulgated by a prior Congress. For instance, if Congress passes a particularly mischievous rule of interpretation that provides that "no statute shall ever be understood as raising tax rates in the absence of the phrase "Congress likes to tax and spend," the constructed meaning derived from the application of the rule of interpretation should not trump a subsequently enacted statute that clearly means to raise taxes. One can imagine an anti-tax Congress passing the rule of interpretation and its rule not really mattering for a period of time because that Congress and those that immediately follow have no interest in rais- 
ing taxes. But if a decade or so later, Congress attempts to pass a tax increase but does not include the mandatory phrase because the mandatory interpretational rule is out of mind, the tax statute means to increase taxes, regardless of the fact that the subsequent Congress did not include the phrase. Whatever the prior mandatory rule might provide, Congress may in effect create an implicit exemption from it by using language in a context that indicates that the latter tax increase is to take effect. An implicit exemption or repeal of the mandate is effective, even though the prior Congress essentially attempted to prevent implicit exemptions and repeals. Thus, Congress cannot enact rules of statutory interpretation. Once again, such "rules" are at best evidentiary guidelines.

All this is so because, in our view, the Constitution presupposes that statutes will be construed consistently with the intentions of the enacting Congress. We do not believe that the Constitution creates this complicated process for enacting a law but then neither supplies nor assumes any method for making sense of what Congress passed, leaving it to the executive or the judiciary to read these statutes however they might see fit, or leaving it to one Congress to dictate a method of interpretation and entrench that interpretation against subsequent implied repeals. Rather than assuming that the constitutional founders created an elaborate structure for writing statutes but wholly failed to provide for a means of making sense of them, we think it far better to suppose that the founders contemplated that statutes (and the Constitution more generally) are to be construed consistently with the intentions of their authors. ${ }^{19}$

If we are right that the Constitution requires a particular means of construing statutes, it follows that Congress does not have any generic right to pass legislation that requires future Congresses to utter certain words or phrases if it wishes to overcome the prior Congress's rules of interpretation. If it is apparent that the subsequent Congress does not want the prior Congress's rules of interpretation to apply to the most recent statute (or more generally does not wish to follow those rules itself), that particularized intention and the resultant meaning must trump the desires of a prior Congress.

To use the language of Rosenkranz, the implicit rule that Congress may use whatever means that it wishes to express itself

19. See supra note 9 for our views on intentionalism and its relation to textualism. 
is a "constitutional mandatory rule" of interpretation. ${ }^{20}$ This constitutional mandatory rule of interpretation is implicit in the presentment clause. ${ }^{21}$ It is not a "default" rule because there is no other power that Congress has to depart from the rule implicit in the presentment clause. None of Congress's substantive powers (e.g., the power to regulate commerce, grant patents, etc.) comes close to authorizing Congress to bind future Congresses to particular ways of repealing or circumventing prior statutes. Moreover, the necessary and proper clause is of no avail either. There is nothing necessary or proper about a statute that attempts to graft onto the presentment clause additional requirements for the passage of legislation. The necessary and proper clause can no more justify mandating that Congress use particular words in order for it to obtain particular legislative ends than it could justify requiring Congress to spin around three times prior to legislating.

Another analogy may help show the difficulties with Congress attempting to pass prospective rules of interpretation that can be neither impliedly repealed nor impliedly excepted from. Suppose the current Supreme Court decrees that its judgments should not be enforced by the executive save when its judgments end with the phrase "Make it so." If in a future case, the Supreme Court (whether or not composed of the current justices) issues judgments without the required words, should the President ignore these judgments? We think not. What matters are the intentions of the Supreme Court justices who authored (or joined) the subsequent judgments issued by the Court. The meaning of the judgments is independent of the completely artificial requirement that a phrase be attached thereto before the executive treats the judgments as executable.

20. Rosenkranz, supra note 1 , at 2109.

21. See U.S. CONST. art. I, \& 7, cl. 2-3.

22. We have rested our case on the nature of interpretation and the constitutional prescription for enacting statutes, and we have argued that entrenchment of rules of construction against implied repeals is not a necessary and proper method of implementing any congressional power over interpretation. If, however, Rosenkranz were to concede this, he might somehow contend that "interpretive" acts like the Dictionary Act were necessary and proper exercises of substantive congressional powers, which exercises could be entrenched against implied repeals. It would then become important to our case that Congress lacks the ability generally to entrench legislation against implied repeals or to entrench particular methods of repeal. Although some have argued that Congress may entrench legislation against ordinary repeal by subsequent Congresses-see, e.g., Eric A. Posner \& Adrian Vermeule, Legislative Entrenchment: A Reappraisal, 111 YALE L.J. 1665 (2002) - we believe that John McGinnis and Michael Rappaport have repudiated that position. See John O. McGinnis \& Michael B. Rappaport, Symmetric Entrenchment: A Constitutional and Normative Theory, 89 VA. L. REV. 385 (2003) 
Or consider a President who announces that future veto statements must contain "I object" if the Congress is to consider them the "objections" required by the presentment clause. Once again, if a President (even the one who adopted the rule) inadvertently fails to include the relevant phrase, Congress should not be free to ignore the fact that the President has in fact expressed his objections and returned the bill. The Constitution grants any President the right to express herself however she wishes. If a President intends to veto a bill and sends to Congress his objections, however expressed, that is all that matters. The veto is complete.

As mentioned earlier, we believe that Congress may pass non-binding interpretive guidelines that might color both how future Congresses might enact legislation and how others will view a future Congress's handiwork. Thus, the fact that Congress has defined marriage in a particular way in the Dictionary Act may make it more likely that a future Congress means to convey that meaning when it uses the word "marriage" in a subsequent statute. What we think is impermissible is a statute that purports to mandate particular definitions for words or particular rules of construction that must be applied by the executive and/or the judiciary in their interpretation of subsequently enacted statutes. When that mandatory interpretive section is applied to a subsequent statute, it may well have the effect that it draws the interpreter away from the statute's true meaning. And when it does that, it violates the implicit constitutional requirement that the meaning of the statute must trump even in the face of the potentially different constructed meaning that might arise from the application of artificial rules of interpretation. Even if Congress is free to repeal expressly or make an express exception to the interpretive rule, that is constitutionally insufficient for giving it effect. Congress may not entrench rules against implied repeal any more than it may against express repeal. ${ }^{23}$

Curiously enough, we think that Rosenkranz is also committed to the proposition that words and sentences have meanings independent of artificial rules of construction. Suppose that section one of a statute provides that "absolutely no rules of construction should be used to construe the rest of this statute." If, after application of whatever rules of construction Rosenkranz currently thinks applicable, it is determined that this statutory language does in fact bar the use of all the rules of construction

23. See supra note 22 . 
created by the courts or by Congress, how would Rosenkranz discern the meaning of the remaining statutory language? If he really believes that meaning merely comes from the application of rules of construction (and is not independent of such rules), then the remainder of this hypothetical statute must mean nothing because, by virtue of section one of the statute, one cannot apply rules of construction to find meaning in the statute. But this seems to us a most improbable way of making sense of words. Prior to the existence of judicially- or congressionallycreated rules of interpretation, people were able to discern the meaning of texts or speech. If that is true, why cannot text today continue to have meaning even in the absence of contrived rules of interpretation?

To think that the meaning of words comes from the application of artificial rules of construction promulgated by branches of the federal government is to adopt an unfortunate government-centric view of words and their meaning. It suggests that the same statute might mean one thing to a federal court and quite another to the state court (assuming that each court is allowed to apply its particular favorite contrived rules of interpretation). We will be so bold as to say that words and sentences have meaning even in the absence of government. More importantly, we believe that words have meanings independent of whatever arbitrary rules that others might create in a bid to stack the deck away from particular substantive outcomes. Such attempts to put a "thumb" on the scale should be recognized for what they are: attempts to drag statutes away from their actual meaning and towards the substantive preferences of those who create the rules of interpretation. ${ }^{24}$ Without a congressional power to add to the constitutional requirements for passing federal legislation, Congress cannot pass mandatory prospective rules of interpretation. As should be obvious, we believe that neither the federal courts nor the Congress has any constitutional authority that enables them to require future Congresses to jump through physical or linguistic hoops prior to legislating.

24. Cf. SCALIA, supra note 9 , at 29 (citing rules of interpretation as thumbs on the scale of interpretation). 